\title{
Magnetized Biochar as a Gold Nanocatalyst Support for $p$-Nitrophenol Reduction
}

\author{
Renata P. Lopes, ${ }^{\circledR *, a, b}$ Tiago Guimarães ${ }^{a}$ and Didier Astruc ${ }^{\oplus *, b}$ \\ a Departamento de Química, Universidade Federal de Viçosa, 36570-900 Viçosa-MG, Brazil \\ ${ }^{b}$ Université de Bordeaux, ISM, UMR CNRS 5255, Talence 33405 Cedex, France
}

\begin{abstract}
The biomass use is of considerable ecological and economical interest and here, biochar, a byproduct of biomass carbonization, is magnetized with $\mathrm{Fe}_{3} \mathrm{O}_{4}$ for its use as gold nanoparticle (NP) support towards catalysis of $p$-nitrophenol (4-NP) reduction. Biochar was synthesized from coffee straw biomass via pyrolysis, while magnetite functionalization was obtained using the precipitation method. The magnetite was identified by X-ray diffraction (XRD). The material had a specific surface area of $30 \mathrm{~m}^{2} \mathrm{~g}^{-1}$ and a zero point charge of 7.5. The gold NPs were deposited via reduction with $\mathrm{NaBH}_{4}$, which yielded $\mathrm{Au}$ and $\mathrm{Fe}_{3} \mathrm{O}_{4} \mathrm{NP}$ of 4.61 and $10.9 \mathrm{~nm}$, respectively. The materials were applied in the 4-NP reduction, with a rate constant $\mathrm{k}_{\mathrm{app}}=(1.2 \pm 0.2) \times 10^{-2} \mathrm{~s}^{-1}$, and a synergistic effect between $\mathrm{Au}$ and $\mathrm{Fe}_{3} \mathrm{O}_{4} \mathrm{NPs}$ was observed. Remarkably, comparison with graphene oxide to which biochar resembles showed similar behavior, and the material was reused in several catalytic cycles.
\end{abstract}

Keywords: biochar, magnetic support, gold nanoparticles, nanocatalysis nitrophenol reduction

\section{Introduction}

Gold nanoparticles (AuNPs) ${ }^{1}$ are known as excellent catalysts for many redox reactions including oxidation by $\mathrm{CO}$ and alcohols by oxygen, epoxidation of propylene, and hydrogenation of multiple carbon-carbon bonds. ${ }^{1-8}$ The AuNP size ${ }^{2,9,10}$ and support nature ${ }^{3,7,8}$ have been shown to play a key role in AuNP stabilization and catalytic efficiency and selectivity. Besides oxides, first popularized by Haruta and Daté ${ }^{2}$ upon synthesis of small AuNPs, active carbons, diamonds, phosphates, among others are current AuNP supports. Engineered support nanostructures have been designed including nanoporous materials (zeolites, mesoporous silica, metal organic frameworks), magnetic materials (iron oxides), and yolk-shell or core-shell nanostructures. ${ }^{7,8}$

Biomass utilization in the context of AuNP catalysis is of fundamental and ecological interest, and biochar is a by-product obtained by biomass carbonization that might be suitable for this application. Biochar (BC) contains stacks of graphite agglomerates with graphene layers and a graphene oxide (GO)-type structure whose edge carbons are potential sites for catalytic synergies with AuNPs. There is thus great interest in the use of biochar as support in catalysis as shown

*e-mail: renata.plopes@ufv.br; didier.astruc@u-bordeaux.fr by a growing literature. ${ }^{11-15} \mathrm{Jiang}$ and co-workers ${ }^{16}$ reported that the addition of magnetite nanoparticles to biochar significantly improved the efficiency of the catalysts, in addition to adding magnetic properties to the material, enabling its easy recovery from the reaction medium and facilitating its reuse.

One of the most common reactions used as a probe to study the activity of new catalysts is the reduction of $p$-nitrophenol (4-NP). ${ }^{17} 4$-NP is known to be a by-product from pesticides, herbicides and synthetic dyes, which can cause damage to the central nervous system, liver, kidney, and both animal and human blood..$^{18}$ This reaction is a "model catalytic reaction" due to the advantages of producing only one product from a simple reagent at mild temperatures and the reaction in the absence of catalyst is very slow. ${ }^{19}$ Significantly, the reaction can be easily monitored by UV-Vis spectroscopy monitoring the absorption decrease of 4-nitrophenolate ions at $400 \mathrm{~nm}^{20}$ $\mathrm{Au}$ and $\mathrm{Pd}^{17}$ nanoparticles (NPs) have the most successful nanocatalysts for this reaction. ${ }^{21}$

The goal of this work was to synthesize AuNPs supported on biochar functionalized with magnetite ( $\left.\mathrm{Au} @ \mathrm{BC}-\mathrm{Fe}_{3} \mathrm{O}_{4}\right)$ and to apply such a BC-based nanocomposite as efficient and recyclable nanocatalyst of $p$-nitrophenol (4-NP) reduction by $\mathrm{NaBH}_{4}{ }_{4}^{18-20,22,23}$ using this cheap ecological biomass-valued support. 


\section{Experimental}

\section{Chemicals and reagents}

Sodium hydroxide (CAS 1310-73-2) was obtained from Fisher (Waltham, USA), and $p$-nitrophenol (CAS 100-02-7) was obtained from Acros Organics (Geel, Belgium). Sodium borohydride (CAS 16940-66-2) and trihydrate chloroauric acid (CAS 16961-25-4) were obtained from Alfa Aesar (Haverhill, USA). Iron sulfate heptahydrate (CAS 7782-63-0) was obtained from Sigma-Aldrich (St. Louis, USA). Hydrochloric acid $37 \%$ (CAS 7647-01-0) was purchased from Quemis (Joinville, Brazil). Aqueous solutions were prepared with water type 1 obtained by Milli-Q system (Millipore Corp., Bedford, MA, USA).

\section{Biochar preparation}

Arabica coffee straw (Coffea arabica) was collected in Espírito Santo-Brazil, latitude: $20^{\circ} 45^{\prime} 49^{\prime \prime}$, longitude: $41^{\circ} 31^{\prime} 59^{\prime}$ 'W. The straw was subjected to a washing step with distilled water and dried to $80{ }^{\circ} \mathrm{C}$ for $48 \mathrm{~h}$. The dry material was ground in a knife mill, and the resulting biomass was then subjected to a pyrolysis stage at $600{ }^{\circ} \mathrm{C}$ in an oxygen-free atmosphere, with a residence time of $4 \mathrm{~h}$. The biochar produced was sieved, which provided 20 to 200 mesh particles.

\section{Synthesis of the materials}

The BC $(2.0 \mathrm{~g})$ was added to $\mathrm{NaOH}\left(20 \mathrm{~mL}, 0.2 \mathrm{~mol} \mathrm{~L}^{-1}\right)$ and $\mathrm{FeSO}_{4} \cdot 7 \mathrm{H}_{2} \mathrm{O}\left(2 \mathrm{~mL}, 1 \mathrm{~mol} \mathrm{~L}{ }^{-1}\right)$. The system was agitated $\left(1 \mathrm{~h}, 100{ }^{\circ} \mathrm{C}\right)$, centrifugated, and the supernatant was removed. The solid was washed with water and dried at $60{ }^{\circ} \mathrm{C}\left(\mathrm{BC}-\mathrm{Fe}_{3} \mathrm{O}_{4}\right)$. BC was obtained under the same conditions, except for $\mathrm{FeSO}_{4}$ addition.

$\mathrm{HAuCl}_{4} \cdot 3 \mathrm{H}_{2} \mathrm{O}(0.275 \mathrm{mmol}$ in $10 \mathrm{~mL}$ ethanol $)$ was transferred to $0.5 \mathrm{~g} \mathrm{BC}\left(\mathrm{BC}\right.$ or $\left.\mathrm{BC}-\mathrm{Fe}_{3} \mathrm{O}_{4}\right)$ and stirred for $3 \mathrm{~h}$. The solvent was evaporated, $\mathrm{NaBH}_{4}\left(10 \mathrm{~mL}, 0.25 \mathrm{~mol} \mathrm{~L}^{-1}\right)$ was added, and the system was stirred $(30 \mathrm{~min})$. After centrifugation, the supernatant was removed. The solid was dried at $60{ }^{\circ} \mathrm{C}\left(\mathrm{Au} @ \mathrm{BC}\right.$ and $\left.\mathrm{Au} @ \mathrm{BC}-\mathrm{Fe}_{3} \mathrm{O}_{4}\right) . \mathrm{GO}$ was synthesized using the Hummers method. ${ }^{24} \mathrm{Au} @ \mathrm{GO}$ and $\mathrm{Au} @ \mathrm{GO}-\mathrm{Fe}_{3} \mathrm{O}_{4}$ were synthesized as described above, except for $\mathrm{BC}$ use.

\section{Characterization}

Fourier transform infrared (FTIR) spectroscopy

The materials were analyzed by Bruker VERTEX 70 instrument (Billerica, USA) using the attenuated total reflection (ATR) method in the range of $350-4000 \mathrm{~cm}^{-1}$.

\section{Raman spectroscopy}

The materials were analyzed by micro-Raman Renishaw InVia spectrometer (Gloucestershire, England) equipped with an Nd-YAG laser $\left(\lambda_{0}=514 \mathrm{~nm}\right)$ and a $50 \times$ objective lens (Olympus $\mathrm{B} \times 41$ ). The acquisition time of Raman spectrum for each sample was set as $10 \mathrm{~s}$.

\section{X-ray diffraction (XRD) analyses}

The materials were analyzed a D8-Discover BRUKER equipment (Massachusetts, USA), equipped with a copper tube (1.5418 $\AA$ ), sweeping the range from 10 to $80^{\circ} 2 \theta$ with a $0.05^{\circ}$ step.

\section{Point of zero charge (PZC)}

The procedure used was adapted from Wang et al. ${ }^{25}$ $20 \mathrm{mg}$ of material was added in $25 \mathrm{~mL}$ of $\mathrm{NaCl}$ solution (0.100 $\left.\mathrm{mol} \mathrm{L}^{-1}\right)$, under 11 different initial $\mathrm{pH}(2,3,4,5,6,8$, $9,10,11,12,13$ ), adjusted by $\mathrm{HCl}$ or $\mathrm{NaOH}$ solutions (both at $0.100 \mathrm{~mol} \mathrm{~L}^{-1}$ ). The system was stirred at $100 \mathrm{rpm}$ and at $25^{\circ} \mathrm{C}$ during $24 \mathrm{~h}$. After this, the solutions were filtered, and the final $\mathrm{pH}$ was analyzed. The PCZ corresponds to the range in which the final $\mathrm{pH}$ remains constant regardless of the initial $\mathrm{pH}$; that is, the surface acts as a buffer. The assays were performed in triplicate.

\section{Transmission electron microscopy (TEM)}

The materials were analyzed by TEM using a JEOL JEM 1400 (120 kV) microscope (Tokyo, Japan).

Surface morphology and elemental analysis of biochar were carried out by scanning electron microscopy (SEM) coupled with X-ray energy dispersive spectrometry (EDS), in a scanning electron microscope, brand JEOL, model JSM-6010LA (Tokyo, Japan). This microscope has a resolution of $4 \mathrm{~nm}$ (with beam at $20 \mathrm{kV}$ ), magnification from $8 \times$ to $300,000 \times$ and acceleration voltage from $500 \mathrm{~V}$ to $20 \mathrm{kV}$. Electron gun was utilized with a pre-centered tungsten filament. An Everhart-Thornley detector provided secondary electron images and solid state detector was used for retro-scattered electrons with contrast of topography, composition and variable shading. A silicon drift detector served for EDS analysis with $133 \mathrm{eV}$ resolution.

\section{4-NP reduction}

$0.15 \mathrm{~mL}$ of a $4-\mathrm{NP}\left(0.80 \mathrm{mmol} \mathrm{L}^{-1}\right), 0.15 \mathrm{~mL}$ of $\mathrm{NaBH}_{4}$ (80 mmol $\left.\mathrm{L}^{-1}\right), 2.70 \mathrm{~mL}$ of water type 1 were added into a cuvette $(1 \mathrm{~cm}$ optical path). Then, $30 \mu \mathrm{L}$ of a material suspension $\left(5 \mathrm{mg} \mathrm{mL}^{-1}\right)$ were added in the system, and the 
time started to be monitored. The system was maintained at room temperature (ca. $25^{\circ} \mathrm{C}$ ) and the reaction was monitored for $10 \mathrm{~min}$ by UV-Vis spectroscopy (Cary 100 Scan, Addison, USA) in full scan mode $(250-500 \mathrm{~nm})$. The experiments were carried out in duplicate.

\section{Results and Discussion}

Different techniques were utilized to characterize the formation of the biochar materials obtained from the carbonization of biomass and magnetite using the chemical precipitation method. First, the BC before and after magnetite and $\mathrm{Au}$ NPs deposition functionalization was analyzed by FTIR, and the results are shown in Figure 1. There were no significant changes after functionalization, with bands at $3352 \mathrm{~cm}^{-1}$ assigned to the stretching of $\mathrm{O}-\mathrm{H}$ bond, $1632 \mathrm{~cm}^{-1}$ assigned to the stretching vibration of carbonyl/carboxyl $(\mathrm{C}=\mathrm{O})$ bond, $1348 \mathrm{~cm}^{-1}$ assigned to the vibration of $\mathrm{C}=\mathrm{C}$ bond, and $1030 \mathrm{~cm}^{-1}$ assigned to the vibration of C-O bonds. ${ }^{15}$ These bands are characteristic of BC from different biomass, such as swine bone, ${ }^{26}$ pine needles of Pinus koraiensis ${ }^{27}$ and sewage sludge. ${ }^{28}$ The magnetic property was also shown by approaching a magnet to the material.

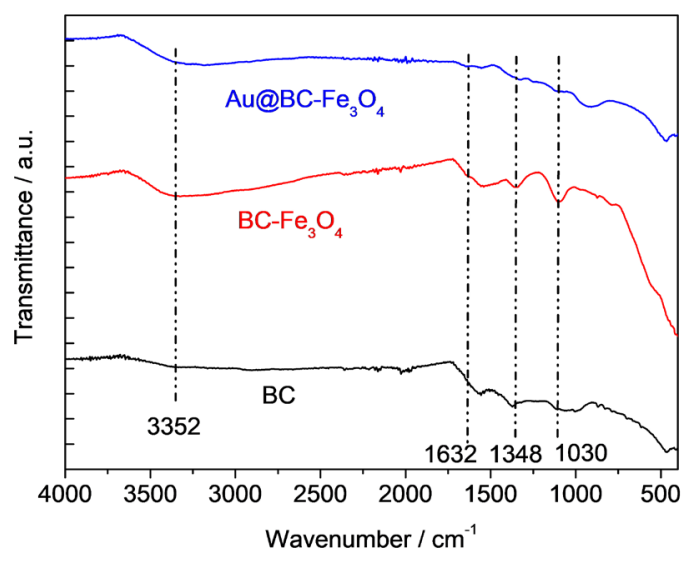

Figure 1. FTIR spectra of $\mathrm{BC}, \mathrm{BC}-\mathrm{Fe}_{3} \mathrm{O}_{4}$ and $\mathrm{Au} @ \mathrm{BC}-\mathrm{Fe}_{3} \mathrm{O}_{4}$.

Another important characterization technique is Raman spectroscopy, for which the results are described in Figure 2. Bands were identified at $1359 \mathrm{~cm}^{-1}$, assigned to the $\mathrm{D}$ band referring to graphite, due to the breathing mode of $\mathrm{A}_{1 \mathrm{~g}}$ symmetry ${ }^{15}$ and at $1580 \mathrm{~cm}^{-1}$, assigned to the $\mathrm{G}$ band referring to amorphous carbon representing the in-plane bond-stretching motion of pairs of $\mathrm{sp}^{2}$ carbon atoms in chains and rings demonstrating the existence of graphitic carbon. ${ }^{15}$ These bands are characteristic of BC and have been described by different authors. ${ }^{26,28}$ The degree of carbon material disorder, obtained by the ratio between the $\mathrm{D}$ intensity band and the $\mathrm{G}$ intensity band $\left(\mathrm{I}_{\mathrm{D}} / \mathrm{I}_{\mathrm{G}}\right)$, is 0.81 . After $\mathrm{BC}$ functionalization with magnetite, a band was observed at $679 \mathrm{~cm}^{-1}$. According to Gasparov et al. ${ }^{29}$ this band can be assigned to the $\mathrm{A}_{1 \mathrm{~g}}$ vibration mode that involves the stretching vibrations of the oxygen atoms along the $\mathrm{Fe}-\mathrm{O}$ bonds.

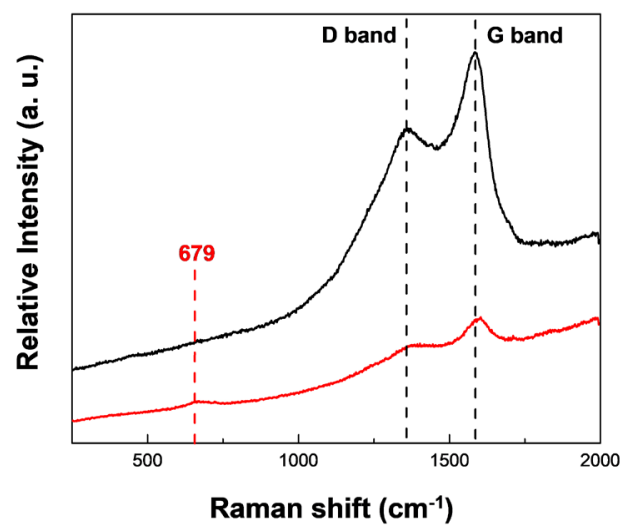

Figure 2. Raman spectra of $\mathrm{BC}$ before (-) and after magnetite functionalization (-).

XRD analyses before and after the functionalization with magnetite and Au NPs depositions are shown in Figure 3.

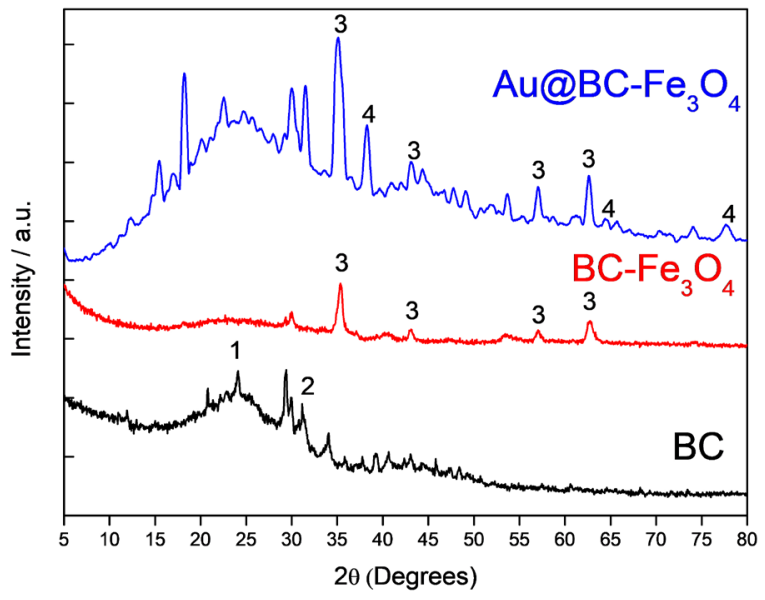

Figure 3. X-ray diffractograms of $\mathrm{BC}$ before and after functionalization. 1: amorphous carbon, 2: silica, 3: magnetite and 4: gold.

The $\mathrm{BC}$ before magnetite functionalization showed a wide peak at $2 \theta=10-30^{\circ}$ that represents the (002) diffraction plan of graphite. ${ }^{15}$ Similar results were also observed in others works inter alia by Wang et al. ${ }^{30}$ and Jiang et al. ${ }^{16}$ The presence of silica $2 \theta=30^{\circ}$ is due to the natural presence of this element in the precursor biomass in the biochar production. ${ }^{31}$ After functionalization, characteristic peaks of magnetite can be observed including peaks $2 \theta$ and their indexed planes are $35.50^{\circ}(311), 43.02^{\circ}(400), 57.03^{\circ}(511)$, $62.70^{\circ}(440) .{ }^{16}$ The diffraction peaks at $2 \theta$ values of 38.35 , 64.6 and $77.7^{\circ}$ are attributed to the (111), (220) and (311) diffractions of the fcc structure of gold. ${ }^{32}$ 
The $\mathrm{N}_{2}$ adsorption/desorption isotherm for $\mathrm{BC}-\mathrm{Fe}_{3} \mathrm{O}_{4}$ is shown in Figure 4. The specific surface area for $\mathrm{BC}$ before and after functionalization was 1.242 and $29.98 \mathrm{~m}^{2} \mathrm{~g}^{-1}$, respectively. Possibly, the increase in the surface area is due to the functionalization step with magnetite, in which a $\mathrm{NaOH}$ solution, widely used as a $\mathrm{BC}$ activating agent, ${ }^{15}$ was used. The presence of $\mathrm{NaOH}$ provokes the separation between the lamellae constituted by plane aromatic compound containing layers of graphene/ graphite structures and the functional groups at the edges of the lamellae, allowing them to completely crinkle. In the presence of water, the lamellae cannot return to their previous state. ${ }^{33}$ Jiang et al. ${ }^{34}$ synthesized magnetic biochar from $\mathrm{FeCl}_{3}$-preloaded sawdust via pyrolysis as support for Pd NPs whose material presented a specific surface area of $340.6 \mathrm{~m}^{2} \mathrm{~g}^{-1}$. In another work, Jiang and co-workers ${ }^{16}$ synthesized $\mathrm{Pd} @ \mathrm{Fe}_{3} \mathrm{O}_{4} /$ biochar with surface area of $295.4 \mathrm{~m}^{2} \mathrm{~g}^{-1}$. The difference in specific surface area can be attributed to biomass and the carbonization process used. The PZC was 7.5. Karunanayake et al. ${ }^{35}$ obtained magnetic BC from waste Douglas fir with PZC of 6.25.

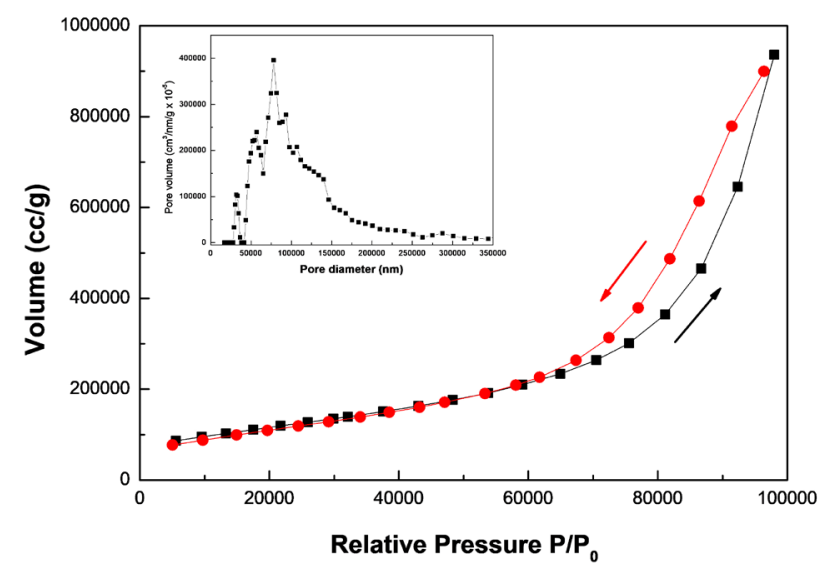

Figure 4. Nitrogen adsorption-desorption isotherms of $\mathrm{BC}-\mathrm{Fe}_{3} \mathrm{O}_{4}$. Inset: pore distribution of $\mathrm{BC}-\mathrm{Fe}_{3} \mathrm{O}_{4}$.
Images obtained by TEM are shown in Figure 5. Quasi-spherical NPs with a size of $10.9 \pm 2.4 \mathrm{~nm}$ are observed in the $\mathrm{BC}-\mathrm{Fe}_{3} \mathrm{O}_{4}$ that can be attributed to magnetite NPs (Figure 5a). Similar results were obtained by Liyanage et al., ${ }^{36}$ who obtained $\mathrm{Fe}_{3} \mathrm{O}_{4}$ particles of $12.3 \pm 7.1 \mathrm{~nm}$ dispersed on the $\mathrm{BC}$ surface. In addition to magnetite, spherical AuNPs are observed with a size of $4.6 \pm 1.0 \mathrm{~nm}$ (Figure 5b). Carbon-based lamellar structures can be seen in Figure 6a. It is also possible to observe the homogeneous distribution of iron on the carbon structure (Figure 6c). As observed by EDS (Figure 7), the elements present in the composition of $\mathrm{Au} @ \mathrm{BC}-\mathrm{Fe}_{3} \mathrm{O}_{4}$ are carbon, iron, silicon, potassium, calcium and oxygen. However, carbon and iron are in greater quantity. Gold cannot be observed by this technique, possibly due to its low sensitivity. However, the presence of AuNPs was clearly observed in the XRD (Figure 3).

The 4-NP reduction by different materials are shown in Figure 8 and Table 1. $\mathrm{BC}-\mathrm{Fe}_{3} \mathrm{O}_{4}$ and $\mathrm{Au} @ \mathrm{BC}$ (Figures $8 \mathrm{~b}-8 \mathrm{c}$ ) presented a similar behavior, with rate constant $\left(\mathrm{k}_{\text {app }}\right)$ of $4.6 \times 10^{-3}$ and $4.7 \times 10^{-3} \mathrm{~s}^{-1}$, respectively. Compared to BC (Figure 8d) that has a $\mathrm{k}_{\text {app }}$ of $9.0 \times 10^{-4} \mathrm{~s}^{-1}$, $\mathrm{Au} @ \mathrm{BC}$ and $\mathrm{BC}-\mathrm{Fe}_{3} \mathrm{O}_{4}$ presented a ca. 5-time larger $\mathrm{k}_{\text {app. }}$. However, $\mathrm{Au} @ \mathrm{BC}-\mathrm{Fe}_{3} \mathrm{O}_{4}$ showed a significantly higher constant $\left(1.20 \times 10^{-2} \mathrm{~s}^{-1}\right)$, with an induction time $\left(\mathrm{t}_{0}\right)$ of only $34 \mathrm{~s}$. These results prove a synergistic effect between AuNPs and $\mathrm{Fe}_{3} \mathrm{O}_{4}$, because the kinetics was significantly higher in comparison to the two materials $\mathrm{BC}-\mathrm{Fe}_{3} \mathrm{O}_{4}$ and $\mathrm{Au} @ \mathrm{BC}$, as can be seen in Table 1 . The reactivity order of the materials was: $\mathrm{Au} @ \mathrm{BC}-\mathrm{Fe}_{3} \mathrm{O}_{4}>\mathrm{Au} @ \mathrm{BC}$ ca. $\mathrm{BC}-\mathrm{Fe}_{3} \mathrm{O}_{4}>\mathrm{BC}$. The efficiency of $\mathrm{BC}$ is compared with $\mathrm{GO}$ (Table 1), and the results are very close with both supports showing a similar tendency. Similar results were obtained by Jiang et al. ${ }^{16}$ who described the 4-NP reduction by Pd@ $\mathrm{Fe}_{3} \mathrm{O}_{4} / \mathrm{BC}$ with $\mathrm{k}_{\text {app }}$ of $2.4 \times 10^{-2} \mathrm{~s}^{-1}$. Sahiner et al..$^{37}$ reported the synthesis of hydrogel based on acrylamide-chicken

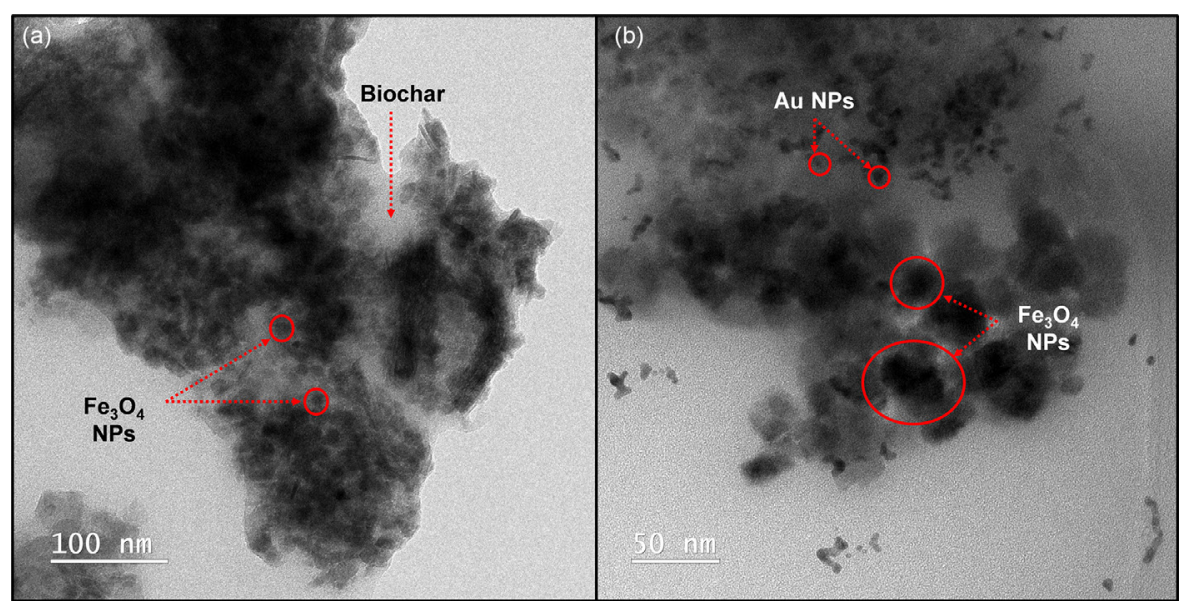

Figure 5. Transmission electronic microscopy (TEM) (a) $\mathrm{BC}-\mathrm{Fe}_{3} \mathrm{O}_{4}$, (b) $\mathrm{Au} @ \mathrm{BC}-\mathrm{Fe}_{3} \mathrm{O}_{4}, \mathrm{Fe}_{3} \mathrm{O}_{4}$ size: $10.9 \pm 2.4$; Au NPs size: $4.61 \pm 1.01 \mathrm{~nm}$. 


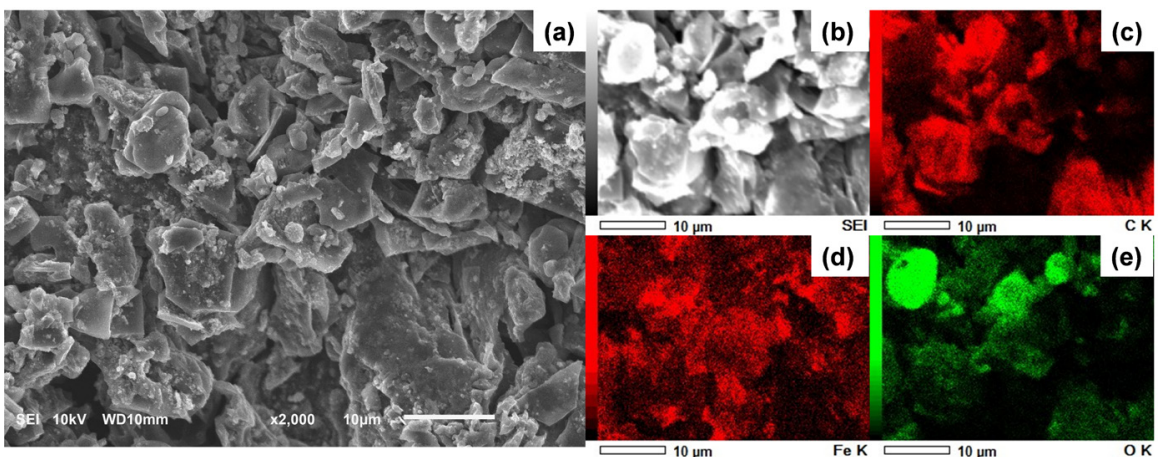

Figure 6. (a) SEM image obtained from $\mathrm{Au} @ \mathrm{BC}-\mathrm{Fe}_{3} \mathrm{O}_{4}$. (b) Mapping of chemical elements by EDS, (c) $\mathrm{C}$ mapping, (d) Fe mapping, (e) $\mathrm{O}$ mapping.

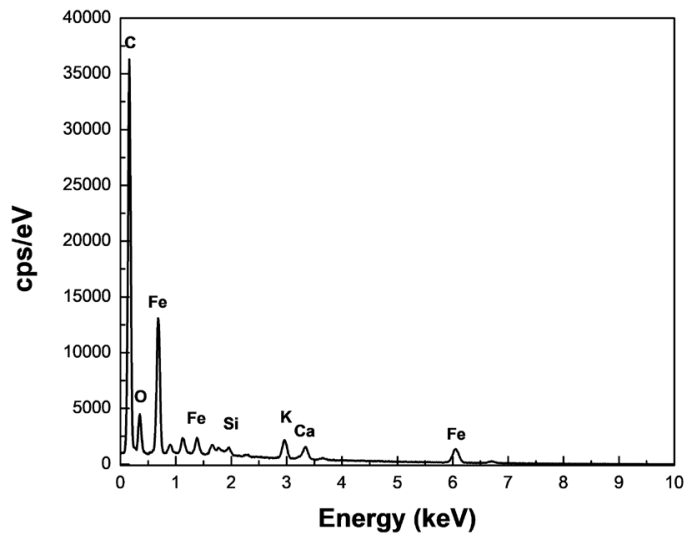

Figure 7. EDS analysis of $\mathrm{Au} @ \mathrm{BC}-\mathrm{Fe}_{3} \mathrm{O}_{4}$.
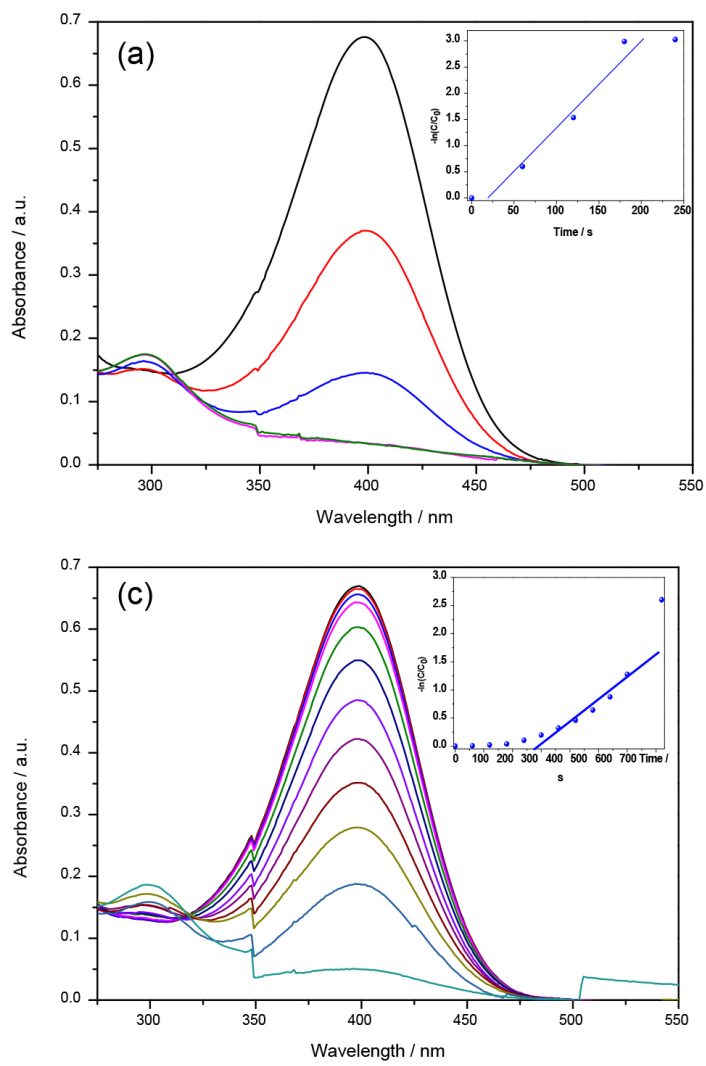

biochar and its use as a template in the preparation of silver metal nanoparticles and applied them to the reduction of $p$-nitrophenol, obtaining a constant kinetics of $6.2 \times 10^{-4} \mathrm{~s}^{-1}$ at $30{ }^{\circ} \mathrm{C}$.

Based on these results, it can be proposed that the $\mathrm{BH}_{4}{ }^{-}$anion coordinates to the AuNPs surface, transferring electrons to it. The epoxy, carboxyl and phenolic groups of BC allow charge distribution between AuNPs and BC. The electrons at the interface of $\mathrm{Au}-\mathrm{Fe}_{3} \mathrm{O}_{4}$ are more active due to different surface energy of AuNPs and $\mathrm{Fe}_{3} \mathrm{O}_{4} \cdot{ }^{32-34}$ Meanwhile, the $p$-nitrophenolate anion is attracted to the positive surface of $\mathrm{BC}$ by electrostatic interactions. The excess electrons facilitate the capture of electrons by 4-NP,
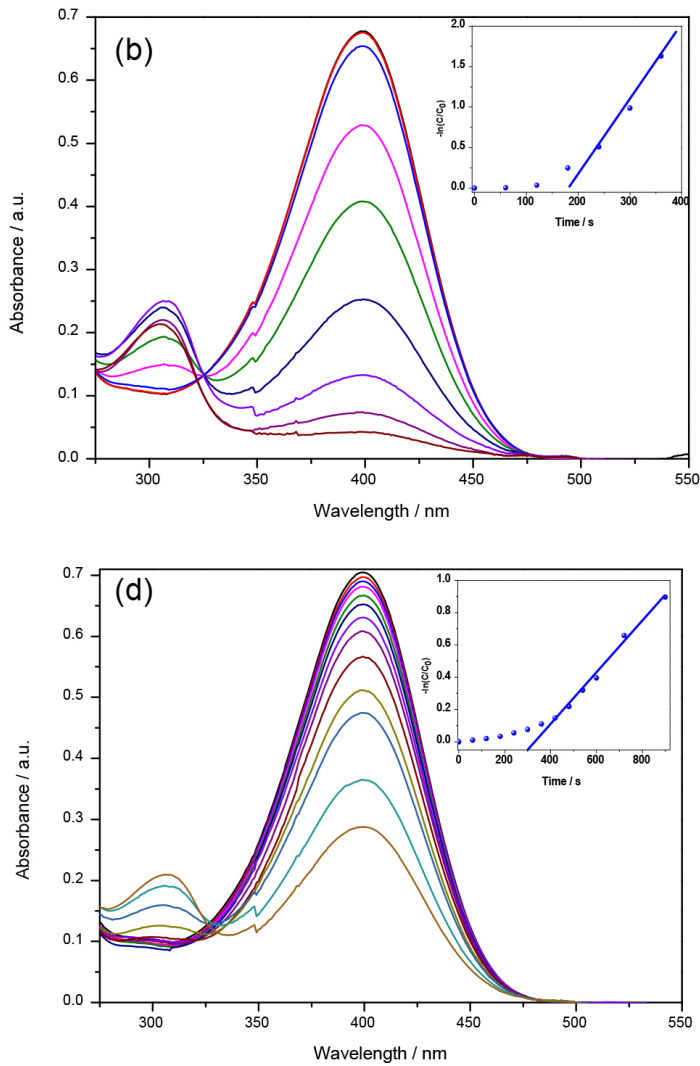

Figure 8. $p$-NP reduction by $\mathrm{NaBH}_{4}$. (a) $\mathrm{Au} @ \mathrm{BC}-\mathrm{Fe}_{3} \mathrm{O}_{4}$, (b) $\mathrm{BC}^{-}-\mathrm{Fe}_{3} \mathrm{O}_{4}$, (c) $\mathrm{Au} @ \mathrm{BC}$ and (d) BC. Conditions: 4-NP: $\mathrm{NaBH}_{4}$ (molar ratio 1:100); catalyst: $30 \mu \mathrm{L}$ of suspension $5 \mathrm{mg} \mathrm{mL}^{-1}$. Inset: $p$-NP reduction by $\mathrm{NaBH}_{4}$ kinetic curve. 


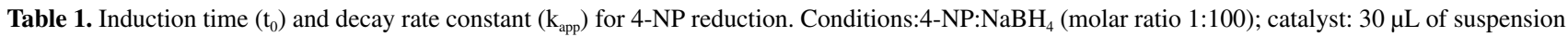
$5 \mathrm{mg} \mathrm{mL}^{-1}$

\begin{tabular}{|c|c|c|c|c|c|}
\hline Material & $\mathrm{t}_{0}{ }^{\mathrm{a}} / \mathrm{s}$ & $\mathrm{k}_{\mathrm{app}} / \mathrm{s}^{-1}$ & Material & $\mathrm{t}_{0} / \mathrm{s}$ & $\mathrm{k}_{\mathrm{app}} / \mathrm{s}^{-1}$ \\
\hline $\mathrm{Au} @ \mathrm{BC}-\mathrm{Fe}_{3} \mathrm{O}_{4}$ & 34 & $(1.2 \pm 0.2) \times 10^{-2}$ & $\mathrm{Au} @ \mathrm{GO}^{\mathrm{b}}-\mathrm{Fe}_{3} \mathrm{O}_{4}$ & 38 & $9.78 \times 10^{-1}$ \\
\hline $\mathrm{BC}-\mathrm{Fe}_{3} \mathrm{O}_{4}$ & 171 & $(4.6 \pm 2.9) \times 10^{-3}$ & $\mathrm{GO}^{\mathrm{b}}-\mathrm{Fe}_{3} \mathrm{O}_{4}$ & 42 & $7.00 \times 10^{-4}$ \\
\hline Au@BC & 271 & $(4.7 \pm 0.9) \times 10^{-3}$ & $\mathrm{Au} @ \mathrm{GO}^{\mathrm{b}}$ & 182 & $6.80 \times 10^{-3}$ \\
\hline $\mathrm{BC}$ & 327 & $(9.0 \pm 4.0) \times 10^{-4}$ & & & \\
\hline
\end{tabular}

The induction time $\left(\mathrm{t}_{0}\right)$ values refer to the inset of Figure 8 ; ${ }^{\mathrm{b}} \mathrm{GO}$ was synthesized using the Hummers method ${ }^{24} \mathrm{BC}$ : biochar; GO: graphene oxide.

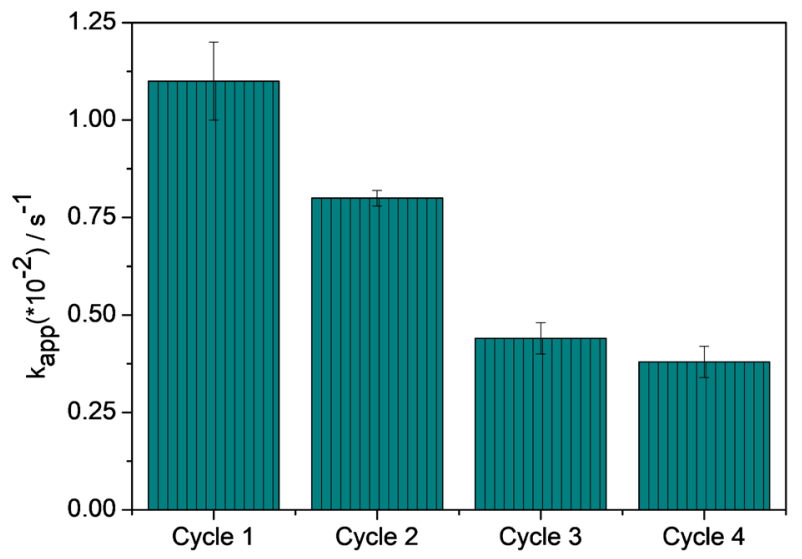

Figure 9. Reusability of the $\mathrm{Au} @ \mathrm{BC}-\mathrm{Fe}_{3} \mathrm{O}_{4}$ catalyst for 4-NP reduction by $\mathrm{NaBH}_{4}$. Conditions: 4-NP: $\mathrm{NaBH}_{4}$ (molar ratio 1:100); catalyst: $30 \mu \mathrm{L}$ of suspension $5 \mathrm{mg} \mathrm{mL}^{-1}$.

allowing their reduction. The release of $p$-aminophenol creates a free surface, and the catalytic cycle starts again. ${ }^{34}$

The reuse of the catalyst was conducted (Figure 9), and the kinetic constant decreased from $1.1 \times 10^{-2}$ for $8.0 \times 10^{-3}, 4.4 \times 10^{-3}$ and $3.8 \times 10^{-3} \mathrm{~s}^{-1}$ in the second, third and fourth cycle, respectively. Despite this decrease, improvements remain potentially feasible, for instance upon $\mathrm{BC}$ functionalization.

\section{Conclusions}

$\mathrm{BC}$ has been used here as a support of Au-catalyzed 4-NP reduction. In addition to contributing to the synergy between $\mathrm{Fe}_{3} \mathrm{O}_{4}$ and AuNPs whose effect consists of approximately 3 -times increase in the 4-NP reduction kinetics, the magnetization allows easy separation of the catalyst, facilitating its reuse. For future research, the functionalization of $\mathrm{BC}$ should improve the catalytic efficiency in multiple catalytic cycles, and this system could be applied to other catalytic reactions.

\section{Acknowledgments}

Financial support from the Coordenação de Aperfeiçoamento de Pessoal de Nível Superior
Brazil (CAPES) for process: 88881.337360/2019-01, CNPq/FAPEMIG (agreement recorded in SICONV: 793988/2013), the University of Bordeaux and the Centre National de la Recherche Scientifique (CNRS) are gratefully acknowledged. The authors thank the physics department of the Universidade Federal de Viçosa for the characterization analyzes.

\section{References}

1. Daniel, M. C.; Astruc, D.; Chem. Rev. 2004, 104, 293.

2. Haruta, M.; Daté, M.; Appl. Catal., A 2001, 222, 427.

3. Ishida, T.; Murayama, T.; Taketoshi, A.; Haruta, M.; Chem. Rev. 2020, 120, 464.

4. Corma, A.; Garci, H.; Chem. Soc. Rev. 2008, 37, 2096.

5. Alshammari, A. S.; Catalysts 2019, 9, 402.

6. Ciriminna, R.; Falletta, E.; Della Pina, C.; Teles, J. H.; Pagliaro, M.; Angew. Chem., Int. Ed. 2016, 55, 14210.

7. Liu, X. Y.; Wang, A.; Zhang, T.; Mou, C.; Nano Today 2013, 8, 403.

8. Sankar, M.; He, Q.; Engel, R. V.; Sainna, M. A.; Logsdail, A. J.; Roldan, A.; Willock, D. J.; Agarwal, N.; Kiely, C. J.; Hutchings, G. J.; Chem. Rev. 2020, 120, 3890.

9. Liu, L.; Corma, A.; Chem. Rev. 2018, 118, 4981.

10. Du, Y.; Sheng, H.; Astruc, D.; Zhu, M.; Chem. Rev. 2020, 120, 526.

11. Qian, K.; Kumar, A.; Zhang, H.; Bellmer, D.; Huhnke, R.; Renewable Sustainable Energy Rev. 2015, 42, 1055.

12. Cha, J. S.; Park, S. H.; Jung, S. C.; Ryu, C.; Jeon, J. K.; Shin, M. C.; Park, Y. K.; J. Ind. Eng. Chem. 2016, 40, 1.

13. Zhang, X.; Gao, B.; Creamer, A. E.; Cao, C.; Li, Y.; J. Hazard. Mater. 2017, 338, 102.

14. Lee, J.; Kim, K.; Kwon, E. E.; Renewable Sustainable Energy Rev. 2017, 77, 70.

15. Lopes, R. P.; Astruc, D.; Coord. Chem. Rev. 2021, 426, 213585.

16. Jiang, S. F.; Ling, L. L.; Xu, Z.; Liu, W. J.; Jiang, H.; Ind. Eng. Chem. Res. 2018, 57, 13055.

17. Lara, L. R. S.; Zottis, A. D.; Elias, W. C.; Faggion Jr., D.; de Campos, C. E. M.; Acuña, J. J. S.; Domingos, J. B.; RSC Adv. 2015, 5, 8289 . 
18. Aditya, T.; Pal, A.; Pal, T.; Chem. Commun. 2015, 51, 9410.

19. Zhao, P.; Feng, X.; Huang, D.; Yang, G.; Astruc, D.; Coord. Chem. Rev. 2015, 287, 114.

20. Hervés, P.; Pérez-Lorenzo, M.; Liz-Marzán, L. M.; Dzubiella, J.; Lub, Y.; Ballauff, M.; Chem. Soc. Rev. 2012, 41, 5577.

21. Wang, Q.; Astruc, D.; Chem. Rev. 2020, 120, 1438.

22. Pradhan, N.; Pal, A.; Pal, T.; Colloids Surf., A 2002, 196, 247.

23. Wunder, S.; Polzer, F.; Lu, Y.; Mei, Y.; Ballauff, M.; J. Phys. Chem. C 2010, 114, 8814.

24. Hummers Jr., W. S.; Offeman, R. E.; J. Am. Chem. Soc. 1958 , $80,1339$.

25. Wang, L.; Zhang, J.; Wang, A.; Colloids Surf., A 2008, 322, 47.

26. Zhou, X.; Zeng, Z.; Zeng, G.; Lai, C.; Xiao, R.; Liu, S.; Huang, D.; Qin, L.; Liu, X.; Li, B.; Yi, H.; Fu, Y.; Li, L.; Wang, Z.; Chem. Eng. J. 2020, 383, 123091.

27. Yan, J.; Yang, L.; Qian, L.; Han, L.; Chen, M.; Environ. Pollut. 2020, 261, 114020

28. Fan, Z.; Zhang, Q.; Gao, B.; Li, M.; Liu, C.; Qiu, Y.; Chemosphere 2019, 217, 85.

29. Gasparov, L. V.; Tanner, D. B.; Romero, H. B. G.; Margaritondo, G.; Forró, L.; Phys. Rev. B: Condens. Matter Mater. Phys. 2000, 62,7939 .
30. Wang, B.; Li, Y.; Wang, L.; Chemosphere 2019, 237, 124454.

31. Guimarães, T.; Teixeira, A. P. C.; Oliveira, A. F.; Lopes, R. P.; New J. Chem. 2020, 44, 3310.

32 Pourhassan, F.; Khalifeh, R.; Eshghi, H.; Fuel 2021, 287, 119567.

33. Marsh, H.; Yan, D. S.; O’Grady, T. M.; Wennerberg, A.; Carbon 1984, 22, 603.

34. Jiang, S. F.; Xi, K. F.; Yang, J.; Jiang, H.; Chemosphere 2019 , 227, 63 .

35. Karunanayake, A. G.; Todd, O. A.; Crowley, M. L.; Ricchetti, L. B.; Pittman Jr., C. U.; Anderson, R.; Mlsna, T. E.; Chem. Eng. J. 2017, 319, 75.

36. Liyanage, A. S.; Canaday, S.; Pittman Jr., C. U.; Mlsna, T.; Chemosphere 2020, 258, 127336.

37. Sahiner, N.; Karakoyun, N.; Alpaslan, D.; Aktas, N.; Int. J. Polym. Mater. 2013, 62, 590.

Submitted: January 11, 2021 Published online: April 19, 2021 